\title{
Proposal for a conceptual frame of reference to study household's food-accessing strategies and utilisation patterns
}

\section{Mmantoa S Kgaphola and Elizabeth Boshoff}

\section{OPSOMMING}

Een van die primêre oogmerke van die Departement Landbou, Bewaring en Omgewing van Mpumalanga is om die voedselsekuriteit van landelike huishoudings te bevorder. Die Afdeling - Landbouhuishoudkunde is verantwoordelik om hierdie proses te fasiliteer. Dit is belangrik dat wanneer huishoudings voedsel geproduseer of bekom het, hulle dit ook op so ' $n$ wyse prosesseer, berg, berei en verbruik dat hulle die grootste nutrisionele, kulturele en sosiale nut uit die voedselverbruik verkry. Tans is die voorligtingsprogramme gerig op hierdie aspekte nie op ' $n$ oorkoepelende benadering gebaseer nie. Om effektiewe voorligtingsprogramme te ontwerp wat landelike huishoudings kan bemagtig met relevante kennis oor die verkryging en verbruik van voedsel vir die verbetering van gesondheid, is dit nodig om relevante kennis oor die konteks waarin landelike huishoudings leef en funksioneer en die wyses waarop hulle voedsel verkry en verbruik sowel as die faktore wat dit beïnvloed in te win. Om die nodige kennis en insig te bekom oor die verkryging en gebruik van voedsel deur landelike huishoudings, is ' $n$ verwysingsraamwerk wat die voedselverkryging en -gebruik holisties benader, saamgestel. Die voorstel is dat hierdie verwysingsraamwerk gebruik kan word wanneer voedselverkrygings- en -verbruikspatrone by landelike huishoudings geanaliseer word. Die verwysingsraamwerk word in hierdie artikel beskryf.

\section{- Ms Mmantoa S Kgaphola}

- Prof Elizabeth Boshoff

Department of Consumer Science, University of Pretoria

\section{INTRODUCTION}

The Integrated Nutrition Programme (INP) as promoted by the Department of Health identifies household food insecurity as one of the underlying causes of malnutrition in South Africa (Department of Health, 2000:4). Rural households especially those situated within the former homelands are the worst affected by poverty because of their inability to command sufficient resources to satisfy basic needs (Department of Social Services, Population and Development, 2001:8; May, 1997:2-11). It is estimated that $72 \%$ of poor people in South Africa live in rural areas and about $70 \%$ of rural people are poor (Ministry of Agriculture and Land Affairs, 1998:1.3).

The Government's White Paper on Agriculture (Department of Agriculture and Land Affairs,1995) commits the Government to addressing both national and household food security. The World Food Summit Plan of Action adopted in 1995 described food security as the situation where all people, at all times, have physical and economic access to sufficient food to meet their dietary needs and preferences for an active and healthy life (Food and Agricultural Organisation of the United Nations, 1998:ix). In the South African context, household food security includes the availability, accessibility and utilisation of food (Food Security Working Group, 1997:4). National food security is fundamental for ensuring individual and household food security because it ensures food availability through agricultural, economic and food policies.

The need to focus on both national and household levels is essential in the promotion of food security. One cannot assume that once food security is met at national level, individuals and households will automatically experience food security. History has taught that a country may be food secured to an extent that it exports food to other countries while a large proportion of its citizens are suffering from hunger and malnutrition. It is therefore important to develop strategies that will facilitate the accessibility of food at individual and household levels. One of these strategies might be to focus on the social institution, the family or household, where people's food-related needs are met or not met.

There is a danger of assuming that once food is physically available individuals and households will automatically benefit from it. Food may be physically available but due to eg sociocultural factors may be unavailable to some individuals. Culture may deter- 
mine what people regard as food, how it is prepared, where and when it is eaten and, in some cases, who consumes it (Fieldhouse, 1995:1-99). Socioeconomic factors such as income, access to arable land and ability to generate income also determine the ability of some households to obtain food either by their own production or through purchasing. Within a given household, the household structure, the food preferences and food attitudes of household members may determine which foods are obtained, what cooking techniques are used, how food is distributed and what the consumption patterns are.

One of the primary objectives of the Department of Agriculture, Conservation and Environment (DACE) in Mpumalanga is to promote household food security and the Division - Agricultural Home Economics is charged with the responsibility of facilitating this process. While it is a joint effort by most of the components of DACE to promote food availability and accessibility, it is the major responsibility of the Division Agricultural Home Economics to promote the optimum utilisation of food by families to help them attain and sustain better health. This responsibility rests on the home economics agricultural officers because of their technical background regarding food utilisation. It is important that once households have produced or accessed food, they also process, store, prepare and consume the food in such a way that they derive optimum nutritional, cultural and social benefits from the food. Otherwise all the efforts employed to make the food available and accessible will be a waste of time and other resources.

Currently the informal education/extension programme offered by DACE dealing with helping households to gain knowledge regarding the production, purchase, storage, processing, preservation and preparation of food to optimise the benefits derived from food are attended to on an ad hoc basis. There are no formal or structured programmes that guide the process and the need for such approaches is felt. For effective informal education programmes that can be used to empower household members with relevant knowledge about accessing and utilising food for the promotion of health, relevant information on which to base such programmes that will enhance the success of the extension programme concerned with food security is necessary.

\section{AIM OF THE ARTICLE}

The aim of this article is to describe and justify a theoretical approach that can be used for studying the food-accessing strategies and utilisation patterns of households in South Africa. The information, knowledge and insight gained through such a study can then form the basis for designing a holistic approach to use in informal education/extension programmes focused on household food security.

\section{FRAMEWORKS USED FOR FOOD-BEHAVIOUR RESEARCH}

Many researchers and scientists working in the field of food or nutrition have suggested frameworks or models that can be used for research in or programmes related to food habits and behaviour, nutrition and food security. The essential characteristics used in some of these original frameworks are summarised below.

De Garine (1972) in Sanjur (1982: 25) suggests that planners of economic and social development programmes related to food should consider at least food-related techniques, actual food consumption and food ideology as the basis for their planning. Foodrelated techniques refer to those techniques relevant and used for food production, storage, distribution, processing and meal preparation. Food consumption includes seasonal fluctuations in food and financial means, and food ideology includes the underlying food-related behaviour including rituals, preferences, dislikes, the prestige value of food and beliefs. Grivetti and Pangborn (1973:208) reviewed different approaches and methods used in food-habit research. They came to the conclusion that multidisciplinary efforts - linking social and clinical science - should be encouraged. A general conclusion from their review is that the environment, cultural and social-functional factors and their interactions are important considerations in food-habit research.

Lund and Burk (1969), as discussed by Sanjur (1982:34-37), designed a conceptual framework for the analysis of the structure of children's behaviour in the consumption of food. In this framework, biological, psychological and sociological needs for food, the food-related knowledge and beliefs as well as the attitudes and values of the child, the family and others in the social milieu of the child are identified as factors that impact on the child's food behaviour. Besides these personal characteristics, situational factors such as the family structure and organisation, the family's social position, economic and meal situation are also impacting on food behaviour. Wenkam's model (1969) of the physical and cultural availability of foods illustrates the many different influences from the physical setting that will influence the availability of food to a household. These are the natural environment, technological development, economic and social forces that influence the production, preservation, distribution, preparation and material culture of people. The cultural availability of foods is defined as the edible material that one's culture considers to be food (Wenkam, 1969 quoted by Sanjur, 1982:42). This is related to characteristics of food such as the social and physical status of a food, the social and ceremonial role played by a food, food etiquette and the division of labour related to the procurement, preparation and serving of food. Wenkam (1969) noted that the physical availability of food is determined by the environment and that the cultural availability arises from the physical availability. Food has different meanings for members of a social group and these meanings 
influence the movement of food from production to ingestion.

In 1978 Sims and Smiciklas-Wright (1978:173-179) proposed the use of the ecological system's perspective in the formation of nutrition policy, programme design and evaluation. According to them, the unique feature of the ecological system's approach is its "focus upon the process by which inputs from the environment are transformed or utilized by the system to produce certain products as outputs of the system" (Sims \& Smiciklas-Wright, 1978:173). Odum (1977), as quoted by Sims and Smiciklas-Wright (1978:174), believes that the ecological perspective promotes a holistic approach, including "linking the natural and social sciences, assessing technological and environmental impacts and bringing together scientific, economic, and politico-legal spheres of action". Sims and Smiciklas-Wright $(1978: 174)$ indicate that the natural environment will determine what kinds of food can be produced, the man-made environment will influence the processing, storing and distribution of food thus influencing the food made available for consumption, while the behavioural environment determines which foods will be chosen from the variety available. According to their model these are the so-called external factors influencing food behaviour. The individual's choice of food will also be influenced by personal factors such as values, attitudes, beliefs and knowledge - the so-called internal or endogenous factors influencing food behaviour.

Jerome, Pelto and Kandel (1980:14) are of the opinion that more comprehensive models are needed to understand human food systems and food-distribution policies and programmes. Jerome et al (1980:13) see household food security as including the household's efforts to find means of providing adequate, palatable, ecologically adaptive and ideologically acceptable diets within a vast range of environmental contexts and cultural patterns. Aspects of the environment identified by them are: the physical environment, technology, social organisation, the social environment and the cultural and ideological systems. The physical environment and technology establish the conditions for food production and distribution, social organisation including the economic and political structures affect access to food while the social environment and the cultural and ideological systems influence the beliefs and attitudes people have about food. They also see household members' physiological and psychological needs forming the core of food choice.

Terry (1994:501-503) identifies aspects of food behaviour and the food environment that have to be understood for providing nutrition services. These aspects are also relevant for providing food security programmes in communities. The identified factors in the food environment of the household and community are: availability, acceptability, safety and the nutritive quality of food, while the factors relating to food behaviour of the household and community are: selection, procurement, distribution, manipulation, storage, consumption and disposal.
A conclusion that can be drawn from the above is that many kinds of foods may be available in a specific geographical or community setting. From this array of possible foods, only a smaller selection is accessible to households or groups, as influenced by sociocultural, technological, economic and politico-legal factors. Again, an even smaller selection of the accessible food will be consumed by any given household or group as determined by many factors, such as the availability of resources, beliefs, attitudes, values, norms and knowledge.

Krondl (1990:12) requires that the formulation of a conceptual framework or a model for studying foodrelated behaviour be as follows: "Conceptual models identify factors and suggest their pathways. Thus they simplify a complex reality such as food selection and become indispensable in designing research in this area".

\section{USTIFICATION OF THE PROPOSED FRAME- WORK FOR THE ANALYSIS OF FOOD- ACCESSING STRATEGIES AND UTILISATION PATTERNS}

As food acquisition and utilisation, especially the consumption of food, is at the core of food security experienced by individuals, it is necessary to start with the family as the basic unit of society where the basic needs of most individuals are met. It should also be possible to identify factors that promote or inhibit the optimum accessing and utilisation of food by individuals if the household is used as the basic unit of analysis. This necessitates an approach that will allow an analysis of the family as a system consisting of different subsystems, eg the personal and managerial subsystems as these relate to food procurement and utilisation by the household. Paolucci, Hall and Axinn (1977), Deacon and Firebaugh (1988) and Engberg (1990) formulated this approach in the family ecological frameworks for household resource management.

In addition to the possibility of analysing the household as a system responsible for food accessing and utilisation, food procurement and utilisation involves the allocation and use of individual and household resources in one way or another. The household is regarded as a system that is responsible for using available resources to meet demands - among others the food and nutritional needs and demands of its members. The resources needed and used for producing, purchasing and utilising food, originate within the household or from the environment in which the household functions and with which it interacts. The ecological approach to family resource management (Paolucci et al (1977), Deacon \& Firebaugh (1988) and Engberg (1990)) provides the necessary conceptual framework for analysing the allocation and use of resources by households.

Furthermore the focus is on food-accessing strategies and utilisation patterns of rural households. The concept strategy refers to a longrange, master plan or 
policy. Strategy is more specifically defined as a guide for making directional decisions involving planning, organising and directing the use of available resources to meet the organisation's objectives among opposing factors in the environment (Banki, 1981; Rosenberg, 1978; French \& Saward, 1983). From this definition it becomes clear that managerial processes such as planning, organising and the allocation of resources are integral to formulating strategies. Food utilisation is the final use of food by individuals at household level. This includes storage, selection, preservation, preparation and the intake of food. These activities rely on the allocation and use of a household's personal and material resources (eg knowledge, equipment available and financial means) and it may be influenced by values, attitudes and norms held in the household or by the individuals concerned. These are two further reasons for the incorporation of the household resource management approach in the framework developed for the study of the food-accessing strategies and utilisation patterns by households.

From the description of the salient aspects of the frameworks suggested for the study of food behaviour (Lund \& Burk, 1969 in Sanjur, 1982; Wenkam, 1969 in Sanjur, 1982; Sims \& Smiciklas-Wright, 1978; Jerome et al, 1980 and Terry, 1994) it follows that to gain the necessary knowledge, insight and information to plan an extension programme aimed at alleviating the food-security situation of households, a holistic approach to studying food-accessing strategies and food-utilisation patterns is necessary.

This approach should therefore include an analysis of the environments impacting on the household with respect to food procurement and utilisation. It should also include those internal factors that influence people's choice of food and the ways in which food is procured and utilised. Following the suggestion that the ecosystem is unique in focussing on the process by which inputs from the environment are transformed or utilised by the system to produce certain products as outputs of the system, an ecosystem perspective would be ideal to use as framework for assessing the processes of food procurement and utilisation patterns of households.

The above considerations led to the choice of the family-ecological frame of reference including the personal and managerial subsystems of the family system for a study of the food-accessing strategies and utilisation patterns of households.

\section{THE FAMILY-ECOLOGY THEORY}

The core assumptions of the family-ecology theory, basic premises of the family-ecosystems perspective and assumptions following from the basic premises were described by Bubolz and Sontag (1993:424425). A selection of the most relevant of these assumptions and premises are stated below as they provide the basic underpinning logic for the proposed conceptual framework.
The family-ecology theory integrates human development and family relationships within a family resource management framework. The theory is a synthesis of assumptions, concepts and propositions from ecology, the general systems theory with its roots in home economics and several other disciplines. Family ecology is a general theory that can be used to study a wide range of problems related to families, regardless of their configuration, and their relationships with various environments including diverse levels and kinds of external systems. The theory focuses on individual family members as well as on the family as a whole considering ways in which families blend tasks and functions of their lives. The theory is useful for research and as an organising framework for familyintervention programmes because it focuses on the whole, thus it has potential to avoid fragmentation of knowledge.

The basic premise holds that the household in interaction with its environment constitute an ecosystem. In an ecosystem the parts and the whole are interdependent (Bubolz \& Sontag, 1993:425; Engberg, 1990:28). If a single factor or component of the system is altered, it affects other components and changes the totality of the system. The family ecosystem carries out physical, biological sustenance, economic maintenance and psychosocial and nurturance functions for its members, itself as a collectivity and for the common good of society (Bubolz \& Sontag, 1993:424).

Relevant basic assumption following from the premise above is that the properties of the household and the environments and the processes taking place within and between them must be viewed as a system; that all parts of the environment are interrelated and influence each other; that the natural environment provides the resource base for life while the sociocultural and man-made environments impacts on the natural environment and is also influenced by the natural environment; that families interact with multiple environments; that interactions between families and environments are guided by physical and biological rules of nature and by man-made rules such as social norms that are related to allocation of resources, role expectations, distribution of power and cultural beliefs that impact on eg the utilisation of food; that the ecosystems perspective requires both sets of rules (the laws of nature and the man-made rules) to be taken into account; that environments do not control human behaviour, but pose limitations and constraints as well as possibilities and opportunities for families, that families have varying degrees of control and freedom with respect to environmental interactions and that decision-making is a central control process in families that directs actions for attaining individual and family goals.

Keeping these core assumptions, the basic premise and the assumptions following from the premise in mind, the following conceptual framework was constructed to incorporate concepts that can be relevant for a study about food-accessing strategies and utili- 
sation patterns of rural households. Theoretical models based on the ecosystem's approach namely those by Paolucci et al (1977), Deacon and Firebaugh (1988), Sims and Smiciklas-Wright (1978), Jerome et al (1980) and Engberg (1990) have been integrated for the development of the conceptual framework. Wenkam's model of the physical and cultural availability of food (Wenkam, 1969 in Sanjur, 1982:37-45) is essentially also an ecological model. Concepts from this model were also considered and included in the framework. Food-related concepts like food ideology (De Garine, 1972 in Sanjur, 1982:25), human needs, food-related knowledge, beliefs, attitudes and values (Lund \& Burk, 1969 in Sanjur, 1982:34-37), and aspects relating to food behaviour and the food environment as suggested by Terry (1994:501-504) were used in compiling the framework (Figure 1).

\section{CONCEPTUAL FRAMEWORK FOR STUDYING FOOD-ACCESSING AND UTILISATION PATTERNS} IN HOUSEHOLDS. (Compiled using mainly Sims \& Smiciklas-Wright, 1978; Paolucci et al, 1977; Jerome et al, 1980; Deacon \& Firebaugh, 1988; Engberg, 1990; Bubolz \& Sontag, 1993).

According to the family ecological models (Bubolz \& Sontag, 1993:425; Engberg, 1990:24) as applied by Sims and Smiciklas-Wright (1978) and Jerome, et al (1980) for studying food habits, the household can be regarded as a system and all the factors that impinge on it as the environment. In this model, the household is seen as a subsystem of the ecosystem that is in interaction with and therefore influenced by factors in the environment. At the same time the household as subsystem is composed of several smaller subsystems that may also have an influence on the ability of the household to access and utilise food.

\section{The environment}

The environment of the household system includes the environment both at the macro-and the microlevels (Deacon \& Firebaugh, 1988:28-38). The macroenvironment includes the natural/structured and the societal systems (Deacon \& Firebaugh, 1988: 2838; Bubolz \& Sontag, 1993: 432).

Natural and structured environment The natural/structured systems are the physical, biological and man-made surroundings within which the societal systems function. They include geographical/natural space with the accompanying biological systems such as plants and animals, and the man-made structures such as buildings, roads and dams. The natu$\mathrm{ral} / \mathrm{structured}$ environment will determine the types of animals and plants viable in a particular geographical area and the type of agricultural production possible (Jerome, et al, 1980:15; Wenkam, 1969 in Sanjur, 1982:38) as well as the infrastructure in a specific area.

Societal subsystems The macroenvironment represented by the societal subsystems namely the political, technological, economic and sociocultural subsystems (Deacon \& Firebaugh, 1988: 30; Eng- berg, 1990:25; Paolucci et al, 1977:27-49; Sims \& Smiciklas-Wright, 1978:173-179; Wenkam, 1969 in Sanjur, 1982:38-45) may influence the availability and accessibility of food. The political subsystem, through its agricultural and food-related policies and regulations and the technological subsystem through agricultural development in food production, processing and transportation may influence the availability of food to communities. According to Jerome et al (1980:15) and Wenkam (1969 in Sanjur, 1982:38) technology refers to tools and techniques of food production and distribution, including agricultural practices, food processing and transportation systems. The economic subsystem influences the income and net worth of households and thus their ability to produce and purchase food. The sociocultural subsystem determines the specific foods that will be chosen and that are acceptable to the cultural and social group to which the family or household belongs (Sims \& SmiciklasWright, 1978:174). With reference to food, the sociocultural system refers to the cultural and ideological systems which include ideas about the role of food in health, religious beliefs involving food, special foods, food restrictions and the use of food in social interactions (De Garine, 1972 in Sanjur, 1982:25; Jerome et al, 1980:15; Terry, 1994:501-504; Wenkam, 1969 in Sanjur, 1982:42-45).

Microenvironment

The microenvironment of a household is composed of the physical and social aspects of the setting within which the household functions. Deacon and Firebaugh (1988:30-31) and Engberg (1990:25-27) see the physical microenvironment as that space occupied and used by the household while the social microenvironment is described as the interaction of the household with its neighbours, relatives and friends. At the microlevel the physical aspects of the village and the social aspects of the community within which the household resides are important since it is the immediate setting within which the household system functions. The physical aspects will determine the infrastructure and facilities available to the household such as water and electricity supply, roads, transport and market-places that influence food availability. The social aspect of the microenvironment may impact on the intracommunity support systems through which food production by a household can be hindered or facilitated.

\section{The household system ${ }^{1}$}

The household system refers to the structure of the household (Paolucci et al, 1977: 53-54 and 74-89) and its intrasystem dynamics and functions (Deacon \&

\footnotetext{
1 Household is used as synonym for family. Family is defined as the basic kinship unit. In its minimal form it consists of a husband, wife and children. In its widest sense it refers to all relatives living together or recognised as a social unit, including adopted persons (Theodorson \& Theodorson, 1969:146). Fairchild (1965:114) defines a family as one or more men living with one or more women in a socially sanctioned and more or less enduring sex relationship, with socially recognised rights and obligations, together with their offspring.
} 


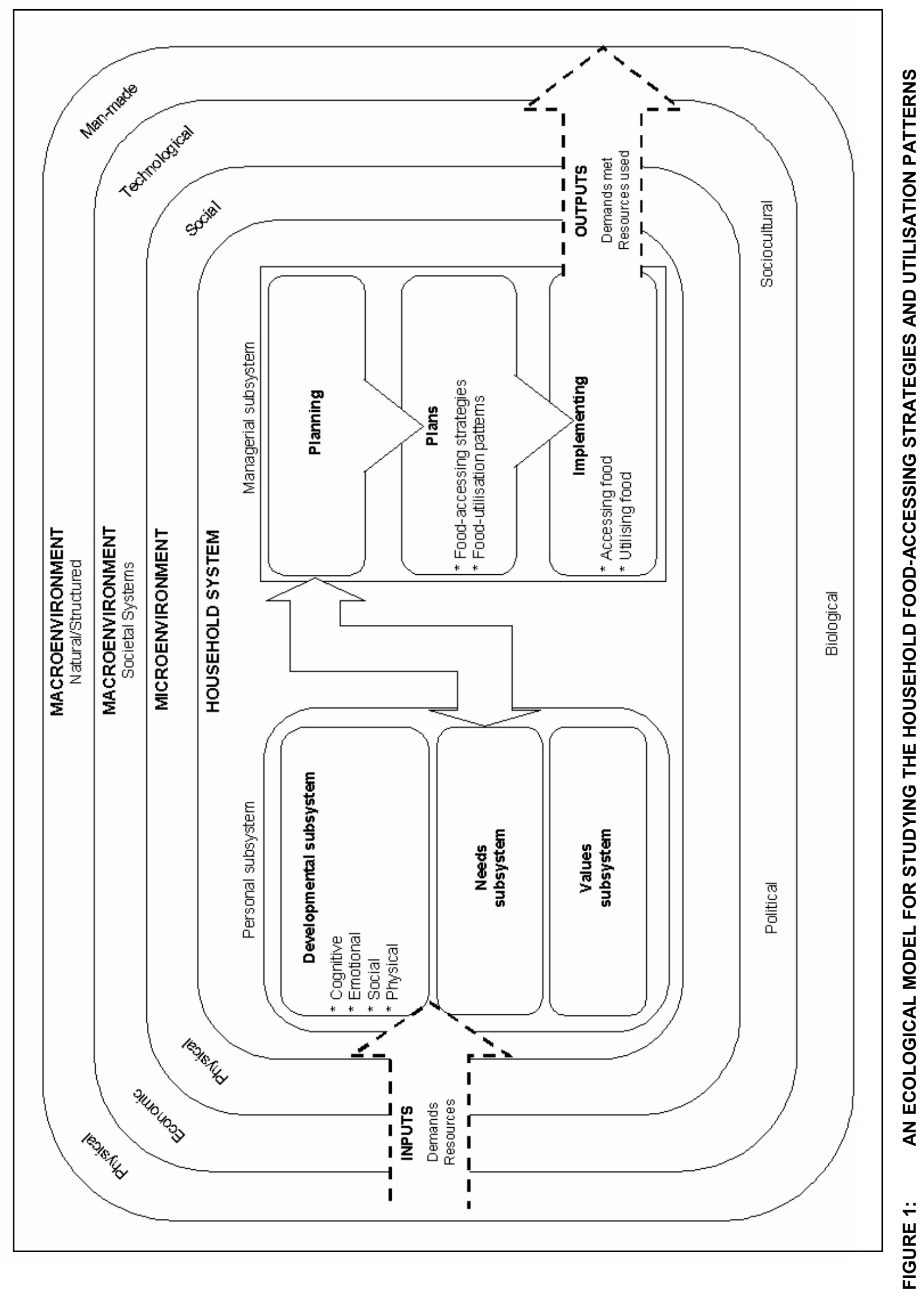


Firebaugh, 1988:21-26). The relationships that occur amongst the members of the household (intrasystem dynamics) and the environment (extrasystem dynamics) help define the functions of the household system. The structure and the stage in the family life-cycle as well as the functions of the household system determine the roles of each household member and the role patterns within a specific sociocultural context. Kayongo-Male and Onyango (1984:11-14) identified four differently structured African family forms, namely nuclear, extended, single-parent and child-headed families. A nuclear family is composed of husband and wife with or without offspring. The extended family includes parents, children and one or more other relatives. A single-parent family can either be female or male headed and child-headed households consist of children only where the older sibling assumes the parental role. The structure of the household also defines the power structures and processes in the African family in terms of authority or leadership structures and decision-making (Kayongo-Male \& Onyango, 1984:27). These in turn determine the family demands and the role patterns. Role expectations and role patterns may be very important in a household's endeavours to access and utilise food. Lund and Burk (1969 in Sanjur, 1982:34-37) indicate that the family structure is one of the factors impacting on the food behaviour of children. In traditional African families roles of men, women and children were very clear and accepted without question (Kayongo-Male \& Onyango, 1984:24). However with the advent of the non-traditional family forms such as single-parent and child-headed families role changes are expected.

According to Paolucci et al (1977:74) family members organise themselves into a system for making decisions about the use of resources. Because each family member is an individual with biological, psychological and social food needs (Burk \& Lund, 1969 in Sanjur, 1982:34-37; Jerome et al, 1980:13), the family organization must serve as an adaptation system and assist members as they interact with one another and with the environment. This adaptation takes place in everyday living by means of activities such as producing and preparing food to fulfil a basic human need.

In the context that a family is seen as an adaptation system through which the basic needs of its members are provided for, food accessing and utilisation are seen as some of the processes of adaptation. The processes of accessing and utilising food both involve obtaining, allocating, transforming and utilising resources in one way or another. Since both processes involve decision-making about the use of household resources they can be seen as managerial processes (Deacon \& Firebaugh, 1988:64; Engberg, 1990:91; Paolucci et al, 1977:128-146). The decisions that the family system makes about the use of resources will determine the quality of living of the system and the viability of the environment that surrounds it (Hagerty, Cummins, Ferriss, Land, Michalos, Peterson, Sharpe, Sirgy \& Vogel, 2001:80; Paolucci et al, 1977:74 -75).

Deacon and Firebaugh (1988:23) use a systems frame of reference for resource management in the household. In this approach the family system is composed of the personal and managerial subsystems that interact through communication processes to develop intrasystem dynamics represented by family cohesion, adaptability and functionality. Deacon and Firebaugh (1988:21) indicated that as daily lives are pursued, the personal and managerial subsystems function as fully integrated entities.

\section{Personal subsystem}

The personal subsystem comprises two subsystems namely the developmental and the values subsystems. In the developmental subsystem the cognitive, emotional, social and physical capacities of family members are developed, while personal experiences and understandings of family members are translated into values and a value system in the values subsystem (Deacon \& Firebaugh, 1988:19). A needs subsystem has been added.

\section{Developmental subsystem}

The development of cognitive capacities includes development of mental competencies such as beliefs, knowledge, decisionmaking and planning abilities. Beliefs are conscious conceptions of the underlying expectations about the physical and social world. They are statements about reality that is accepted as true and factual based on empirical observation, logic, tradition and acceptance by others. Beliefs form the basic structure of an individual's conception of the world. They provide the basic framework and cognitive structure within which a person's perceptions occur (Theordorson \& Theodorson, 1969:28-29). Knowledge forms part of the cognitive capacities of people. It refers to the accumulations of facts and the ability to see functional relationships between them (Paolucci et al, 1977:137). It entails the body of shared and relatively standardised explanations and interpretations of a variety of phenomena from natural occurrences to social behaviour and containing solutions to everyday problems. Knowledge includes indigenous knowledge acquired through socialisation and apprenticeship. Lund and Burk had already illustrated the importance of beliefs and knowledge for food practices in 1969 (quoted in Sanjur, 1992:34-37). This was corroborated by Sims and Smiciklas-Wright (1978:174).

Louw, Schoeman, van Ede \& Wait (1991:346-347) state that emotional development includes learning to cope with emotions such as anger, love, fear and aggression. According to Drever (1964:10) affect is any kind of emotion or feeling attached to ideas or ideacomplexes. Other characteristics of people concerning their emotion/affect - like attitudes - are also learned in the family. According to Baron and Byrne (1991:138) attitudes are "enduring mental representations of various features of the social or physical world". Attitudes are acquired through experience and exert a directive influence on subsequent behaviour, thus they have a strong relationship with actions (Baron \& Byrne, 1991:142-144). Drever's definition (1964) of attitude as a more or less stable set or disposition of opinion, interest, or purpose, involving ex- 
pectancy of a certain kind of experience, and readiness with an appropriate response emphasizes the fact that specific attitudes have a strong relationship with actions. Attitudes are considered to be goal facilitating when positive or inhibiting when negative (Kilby, 1993:39). A person's attitude towards eg work of a certain type may influence the ability of a household to produce food. As illustration of the long-standing importance of attitudes in food behaviour two early frameworks on food-behaviour already included attitudes as a concept (Lund \& Burke, 1969 in Sanjur, 1982:34-37; Sims \& Smiciklas-Wright (1978:174).

Social development encompasses the learning of appropriate roles and role expectations in the specific sociocultural context (socialization). It also includes the development of norms. A social norm is defined as "a rule or standard of behaviour defined by the shared expectations of two or more people regarding what behaviour is to be considered socially acceptable. Social norms provide guidelines to the range of behaviour appropriate and applicable to particular social situations. Thus one's role obligations in a social group are defined by that group's social norms" (Theodorson \& Theodorson, 1969:276-277).

Physical development is associated with physical growth and the associated developmental tasks as well as the acquisition of psychomotor skills.

The values subsystem The values subsystem "translates experiences and understanding into intrinsic and extrinsic meanings" (Deacon \& Firebaugh, 1988:19). Theodorson and Theodorson (1969:455457) describe value(s) as follows: "An abstract, generalized principle of behaviour to which the member of a group feels a strong, emotionally toned positive commitment and which provides a standard for judging specific acts and goals ... Values provide essential organizing principles for the integration of individual and group goals". The emphasis in this definition is on group values. At the individual level a value is referred to as a value orientation and it is seen as a value to which an individual is committed and which influences his/her behaviour. Lund and Burk (1969 in Sanjur, 1982:34-37) and Sims and Smiciklas-Wright (1978:174) included values as concept in their frames of reference for studying food-related behaviour.

The cognitive, emotional, physical and social capacities developed through the developmental subsystem can also be seen as personal resources which can be utilized by the family system in striving towards the achievement of their goals or in reacting to demands made by the environments on their system. Norms and attitudes are important factors in human behaviour. Values are seen as important for the definition and clarification of goals in the family system. Another aspect that should be seen as part of the personal subsystem is the personal needs of household members.

Human needs A need is defined as a condition marked by the feeling of lack or want of something, or of requiring the performance of some action (Drever, 1964). According to Maslow's theory of needs (Goble, 1971), needs are organized in a hierarchical structure and these needs initiate goal-directed behaviour. Maslow's theory states that before an individual is motivated by a need, needs at a lower level in the hierarchy should be fairly satisfied first. The hierarchy of needs are, from the lowest to the highest: physiological needs, safety needs, belongingness and love needs, esteem needs and self-actualisation needs (Paolucci et al, 1977:58-63). Thus, needs at all the levels as identified by Maslow and as experienced by household members will be important motivators in the household's decisions about goals to strive for. Burk and Lund in 1969 already indicated the importance of biological, psychological and social needs related to food behaviour in their frame of reference for studying food behaviour (in Sanjur, 1982:34-37).

\section{The managerial subsystem}

Goals, set in the personal system of the family system, enter the second subsystem - the managerial system - as input. The managerial system is seen as consisting of two subsystems, the planning subsystem and the implementing subsystem. The plans, originating from the planning subsystem, are the inputs for the implementing subsystem. In the planning subsystem, goals are refined, resources are allocated and actions and their sequences are planned. The result of these processes and decisions are plans (Deacon and Firebaugh, 1988:78-92).

Different kinds of plans can be generated through the planning process. Writers about household resource management identify three types of plans, namely single-use, repeat-use and metaplans. Single-use plans are used only once as the name indicates. Repeat-use plans are made and used over and over again. Their value is that they establish a pattern of actions (routines) for everyday, recurring activities. These plans tend to centre around repetitive activities and established patterns of work, their use give structure to life and such plans are very valuable management tools. Metaplans are plans from which a large number of different plans can be generated (Deacon \& Firebaugh, 1988:85; Boshoff, 1994:11-12). As indicated previously a strategy is seen as a longrange master or metaplan. It is expected that a household will develop such longrange plans through which they will be able to meet their goal of getting food for consumption to meet the food-related needs of the household members. Food-accessing strategies that households have will thus be the outcomes of planning behaviour. These strategies should then include the specific goals to be met, the resources allocated to accomplish these goals and the planned actions that would be necessary to accomplish the goals. As indicated above, plans that are used repeatedly acquire the characteristics of patterns of behaviour. It is also expected that a household will develop such patterns regarding how to utilise the food at their disposal. Food-utilisation patterns of households will thus also be an outcome of planning behaviour. 
Implementing refers to actually starting the tasks necessary to put the plans into practice, as well as checking the progress made and if necessary to change the plans (Deacon \& Firebaugh, 1988:93-104).

A systems approach to household resource management further allows that input into the system is in the form of demands and resources originating from outside as well as inside the system. Deacon and Firebaugh (1988:8-10) describe demands as goals and/or events requiring action by the household. These goals may originate in the personal subsystem of the family system or may result from policies, actions, events, etc in the environment of the household. Goals and events give direction to managerial processes and activities.

Likewise, resources - described as means with the necessary characteristics or the properties needed for meeting the demands placed on the household - can originate in the environment or in the family system. Resources are usually divided into two classes, namely material and personal resources (Deacon \& Firebaugh, 1988:52-57; Paolucci et al, 1977:136-137). The outputs of the system are seen as demands that have been met and resources that have been exchanged, used, developed, transferred or saved (Deacon \& Firebaugh, 1988:114-122)

In this case the inputs can be seen as the household food demands and the related resources available to the household to use for making food available and to utilise the food to lead to the output of met demands and resources that have been changed in different ways. The resources include both human and material resources (eg knowledge of food production, and money for seed) and may be either tangible or intangible. The output will be the responses to the food demands made on the household, including satisfaction with goals accomplished and resources that have been changed/used/transferred as a result of the transformation process. In this case the output is adequate food supply and meals that meet cultural, social, emotional and physiological food-related goals.

The throughput will involve all the processes that the household employs to transact with its environment to access and utilise household food to meet the food needs of the household members. Household resource management in this regard is seen as the process through which the household transforms inputs into outputs. This transformation process involves both the personal subsystem of the household and the managerial subsystem. As indicated above, the personal subsystem includes the developmental and the value subsystems and needs. The developmental subsystem includes the cognitive (food-related beliefs, knowledge and information), the emotional (food-related attitudes, likes, dislikes and preferences) the social (roles, norms) and physical/psychomotor skills and capabilities. Goals set for household food security need to be translated into plans (strategies and repeat use plans/patterns) that must be imple- mented to achieve the goal of providing meals that are nutritionally adequate and socially and culturally acceptable to household members

\section{CONCLUSION}

To obtain a full understanding of how rural households access and utilise food, it is suggested that all the aspects mentioned in the proposed framework should be investigated. The knowledge, insight and understanding gained by taking a holistic view in studying food-accessing strategies and foodutilisation patterns by households, can then be used as a basis for planning an approach to use when agricultural home economics extension officers engage with communities in food-security programmes.

To achieve this end, a framework was compiled by using an ecological approach where the household is viewed as in interaction with the different subsystems of the macro- and microenvironments in which it lives. Furthermore, the household as system in which basic human needs are satisfied through intrasystem processes related to personal development and management of household resources to accomplish household goals, was incorporated as the focus of the framework. The aspect that differentiates this framework from other similar frameworks is the emphasis on the household's managerial subsystem. Foodaccessing strategies and utilisation patterns are essentially types of plan that households have for obtaining and using food to satisfy basic needs. This framework can be used to analyse and interpret the plans households have, what resources are used, who is responsible for implementing the plans and what contextual (exogenous) and endogenous factors impact on these plans and their implementation. With this kind of knowledge available, an extension service can then plan an approach to use in executing foodsecurity programmes tailored for the clientele in a specific context.

\section{REFERENCES}

BANKI, IS. 1981. Dictionary of administration and management. Los Angeles. Systems Research Institute.

BARON, RA \& BYRNE, D. 1991. Social psychology. Understanding human interaction. London. Allyn \& Bacon.

BOSHOFF, E. 1994. Satisfaction with managerial role performance and plans used in Pretoria households. Journal of Dietetics and Home Economics 22(1):11-18

BUBOLZ, MM \& SONTAG, MZ. 1993. Human ecology theory. In Boss, PG, Doherty, WJ, LaRossa, R, Schumm, WR \& Steinmetz, SK (eds). 1993. Sourcebook of family theories and methods. A contextual approach. New York. Plenum.

DEACON, RE \& FIREBAUGH, FM. 1988. Family resource management. Principles and application. $2^{\text {nd }}$ ed. Boston. Allyn \& Bacon. 
DEPARTMENT OF AGRICULTURE AND LAND AFFAIRS. 1995. White paper on agriculture. Pretoria. Department of Agriculture.

DEPARTMENT OF HEALTH. 2000. Integrated nutrition programme: A foundation for life. Issue 2. Pretoria. The National Department of Health.

DEPARTMENT OF SOCIAL SERVICES, POPULATION AND DEVELOPMENT: POPULATION UNIT. 2001. Demographics of poverty in Mpumalanga. Revised ed. Nelspruit. The Provincial Department of Social Services, Population and Development, Mpualanga.

DREVER, J. 1964. A dictionary of psychology. Revised by $\mathrm{H}$ Wallerstein. Aylesbury. Hazell Watson \& Viney.

ENGBERG, LE. 1990. Rural households and resource allocation for development. An ecosystem perspective. Rome. Food and Agricultural Organisation of the United Nations.

FIELDHOUSE, P. 1995. Food and nutrition. Customs and culture. $2^{\text {nd }}$ ed. London. Chapman \& Hall. FOOD AND AGRICULTURAL ORGANISATION OF THE UNITED NATIONS. 1998. Rural women and food security: current situations and perspective. Rome. Food and Agricultural Organisation of the United Nations.

FOOD SECURITY WORKING GROUP (AGRICULTURAL POLICY UNIT). 1997. Food security policy for South Africa. A discussion document. Pretoria. The National Department of Agriculture and Land affairs.

FRENCH, D \& SAWARD, H. 1983. Dictionary of management. $2^{\text {nd }}$ ed. Cambridge. University Press.

GOBLE, F. 1971. The third force. The psychology of Abraham Maslow. A revolutionary new view of man. New York. Pocket Books.

GRIVETTI, LE \& PANGBORN, RM. 1973. Food habit research: A review of approaches and methods. Journal of Nutrition Education 5(3):204-208.

HAGERTY, MR, CUMMINS, RA, FERRISS, AL, LAND, K, MICHALOS, AC, PETERSON, M, SHARPE, A, SIRGY, J \& VOGEL, J. 2001. Quality of life indexes for national policy: Review and agenda for re- search. Social Indicators Research 55:1-96.

JEROME, NW, PELTO, GH \& KANDEL, RF. 1980. An ecological approach to nutritional anthropology. In Jerome, NW, Kandal, RF \& Pelto, GH. 1980. Nutritional anthropology. New York. Redgrave.

KAYONGO-MALE, D \& ONYANGO, P. 1984. The sociology of the African family. London. Longman. KILBY, RW. 1993. The study of human values. London. University Press of America.

KRONDL, M. Conceptual models. In Anderson, HG. 1990. Diet and behaviour. Multidisciplinary approaches. London. Springer-Verlag.

LOUW, DA, SCHOEMAN, WJ, VAN EDE, DM \& WAIT, J. 1991. Middle childhood. In Louw, DA. 1991. Human development. Pretoria. Kagiso Tertiary.

MAY, J. 1997. Food security situation in South Africa. In Food Security Working Group (Agricultural Policy Document) 1997. Food security policy for South Africa. Pretoria. The National Department of Agriculture and Land Affairs.

MINISTRY FOR AGRICULTURE AND LAND AFFAIRS. 1998. Agricultural policy in South Africa: A discussion document. Pretoria. Ministry for Agriculture and Land Affairs. Accessed on http://www.nda.agric.za/docs/policy98.htm.

PAOLUCCI, B, HALL, AO \& AXINN, N. 1977. Family decision making. An ecosystem approach. Wiley. New York.

ROSENBERG, JM. 1978. Dictionary of business and management. New York. Wiley-Interscience.

SANJUR, D. 1982. Social and cultural perspectives in nutrition. Englewood Cliffs, NJ. Prentice Hall.

SIMS, LS \& SMICIKLAS-WRIGHT, H (1978): An ecological systems perspective. Its application to nutrition policy, program design and evaluation. Ecology of Food and Nutrition 7: 173-179.

TERRY, RD. 1994. Needed: A new appreciation of culture in food behavior. Journal of the American Dietetics Association 94(May):501-503.

THEODORSON, GA \& THEODORSON, AC. 1969. A modern dictionary of sociology. New York. Thomas $Y$ Cromwell. 